„Analiza i Egzystencja” 45 (2019)

ISSN 1734-9923

DOI: $10.18276 /$ aie.2019.45-02

\title{
MIROSŁAW RUTKOWSKI
}

\section{KRZYWDZENIE A PRZYZWALANIE NA KRZYWDE. CZĘŚĆ I: STATUS OSOBY POSTRONNEJ}

Słowa kluczowe: krzywdzenie, przyzwolenie na krzywdę, Maszyna Tooleya, zasada moralnej symetrii, osoba postronna

Keywords: hurting, allowing harm, Tooley's machine, the principle of moral symmetry, third party

Wielu ludzi skłonnych jest sądzić, że nie ma istotnej różnicy moralnej między umyślnym krzywdzeniem kogoś a przyzwoleniem na jego krzywdę. Pogląd ten opiera się zwykle na przekonaniu, że w jednym i drugim wypadku osoba będąca ofiarą dziejącej się krzywdy może ponieść szkody, które wywołają u niej takie cierpienie, i tak niekorzystnie wpłyną na jej interesy, że słusznie będzie twierdzić, że w obu sytuacjach doświadcza ona podobnej niesprawiedliwości. Każdy, kto tak uważa, może stosunkowo łatwo dojść do wniosku, że skoro zabrania się, aby w sposób zamierzony oraz bez odpowiedniego

* Mirosław Rutkowski - profesor US, kierownik Zakładu Etyki w Instytucie Filozofii Uniwersytetu Szczecińskiego. Prace naukowe z zakresu metaetyki, etyki normatywnej oraz etyki praktycznej.

Adress for correspondence: Mirosław Rutkowski, University of Szczecin, Faculty of Philosophy, Krakowska 71-79, 71-017 Szczecin. E-mail: rutkowski1957@gmail.com. 
uzasadnienia powodować czyjąś krzywdę, to - jeśli prawdą jest, że nie ma moralnie istotnej różnicy pomiędzy działaniami polegającymi na tego rodzaju bezpośrednim i rozmyślnym czynieniu krzywdy a tymi, które jedynie sprowadzają się do przyzwolenia na czyjąś krzywdę (poprzez jakiś rodzaj postępowania umożliwiającego w efekcie jej zaistnienie lub skutecznie podtrzymującego dalsze jej trwanie) - za niedopuszczalne należałoby również uznać wszelkie próby powstrzymywania się od zapobieżenia krzywdzie wtedy, kiedy bez trudu można by jej zapobiec.

Dlaczego ta kwestia wydaje się tak ważna i dlaczego niektórzy stanowczo obstają przy takim rozróżnieniu, a inni pragną za wszelką cenę je odrzucić lub, w najlepszym razie, pomniejszyć jego moralną doniosłość? Istota rzeczy tkwi prawdopodobnie w tym, że ci, którym przynależy w tej sprawie słuszność, otrzymują przyzwolenie na to, aby dyktować pozostałym nie tylko to, co mogą, a czego nie mogą robić w swoim życiu, ale również to, czego w ogóle nie wolno im czynić oraz co czynić pod adresem innych ludzi bezwzględnie muszą. Jeżeli bowiem zgodzimy się co do tego, że nikt nie powinien świadomie szerzyć zła, i w związku z tym nie powinien przyczyniać się do powstania czyjejkolwiek krzywdy, gdy nie ma dobrej racji do podobnego postępowania, to teza o braku takiego rozróżnienia może skutkować tym, że będziemy musieli założyć, iż mamy obowiązek, by zapobiegać cudzej krzywdzie wszędzie tam, gdzie istnieje taka możliwość.

Trzeba przyznać, że idea ta ma wielu zwolenników i jest używana nie tylko jako pewien typ logicznej argumentacji w celu ustalenia najbardziej wiarygodnego stanowiska w tak ważnych sprawach, jak aborcja, eutanazja czy obowiązek udzielania pomocy ludziom cierpiącym biedę, ale służy również do wywierania społecznego nacisku i napiętnowania osób, które myślą inaczej, albowiem uważają, że powinniśmy naprawiać tylko szkody, jakie sami wyrządzamy, i nie widzą przekonujących argumentów za tym, żeby obarczać nas tak poważną obligacją na rzecz tych, którzy nie doznali w ten sposób krzywdy z naszej strony (Narveson, 2003, s. 419-420).

Ci, którzy podejmują się trudu rozwikłania tego problemu, są na ogół przekonani, że znalezienie jednoznacznego rozwiązania, choć z pewnością niełatwe i wymagające mozolnej pracy, jest jednak możliwe, oraz że jeśli to nastąpi, będziemy mogli w końcu dowiedzieć się, po której stronie sporu leży ostateczna racja. Myślę, iż tego rodzaju oczekiwania, choć zrozumiałe, są jednakże zbyt optymistyczne. Aby je spełnić, należałoby najpierw znaleźć empiryczne kryteria pozwalające każdorazowo na odróżnienie 
czynności krzywdzenia od zachowania, które jest nieodłącznie związane z przyzwoleniem na krzywdę, a następnie trzeba by sformułować jakąś ogólną i normatywną regułę, na podstawie której taką lub inną porównawczą wartość tego typu czynów można by stosować wszędzie tam, gdzie mielibyśmy - lub moglibyśmy mieć - do czynienia z takimi właśnie przypadkami postępowania. Wydaje się, że żaden z tych warunków nie jest możliwy do zrealizowania w tej postaci, jaka jest konieczna do osiągnięcia założonego celu. Niezliczona wprost liczba faktów i okoliczności mogących towarzyszyć powstaniu krzywdy, które musiałaby brać pod uwagę każda rzetelna próba określenia pozamoralnej różnicy między czynnościami polegającymi na krzywdzeniu i przyzwoleniu na krzywdę, powoduje, że znalezienie w tym zakresie jakiegoś jednego i uniwersalnego kryterium różnicującego staje się mało realne. Ma to między innymi taki skutek, że nie jest również możliwe, aby każdy przypadek krzywdzenia różnił się moralnie w taki sam sposób od każdego przypadku przyzwolenia na krzywdę (McMahan, 1993, s. 273).

Zacznę od dość istotnej dla poruszanego tematu sprawy, która w dotychczasowych analizach albo nie została dostatecznie jasno wyeksplikowana, albo w ogóle nie była podnoszona, a która, jak sądzę, stanowi często główną przyczynę tego, że sprzeczne ze sobą wnioski, jakie z nich wyciągano, opierały się na pewnych, nie do końca uświadomionych, nieporozumieniach; sprawa ta w istotny sposób wiąże się z pytaniem, jakiego rodzaju przypadków krzywdzenia i przyzwolenia na krzywdę ma dotyczyć kwestia moralnej różnicy między nimi:

1. Czy sądy moralne na ten temat mają odnosić się wyłącznie do przypadków idealnych, tj. całkowicie wyizolowanych ze społecznego kontekstu, w ramach których pod uwagę bierze się tylko to, co jest konieczne, aby móc dokonać pojęciowego rozróżnienia pomiędzy krzywdzeniem a przyzwoleniem na krzywdę?

2. Czy w tego typu sądach uwzględnia się również jakieś dodatkowe zewnętrzne czynniki, które mogą towarzyszyć krzywdzeniu i przyzwoleniu na krzywdę, zakładając jednakże, że w każdym przypadku muszą być one takie same?

3. Czy też porównuje się ze sobą przypadki, które, choć spełniają wymagane kryteria dla czynności krzywdzenia i przyzwolenia na krzywdę, charakteryzują się ponadto zupełnie odmiennymi własnościami? 
Większość zwolenników poglądu głoszącego brak moralnie znaczącego rozróżnienia między krzywdzeniem a przyzwoleniem na krzywdę odpowiada pozytywnie na dwa pierwsze pytania, twierdząc jednocześnie, że krzywdzenie może być uznane za dużo gorsze w warunkach, których wystąpienie implikuje pytanie trzecie, tj. wszędzie tam, gdzie porównywanie wartości obu sposobów postępowania odbywa się w obecności pewnych czynników zewnętrznych, które charakteryzują jedynie czynność krzywdzenia i nie mają zastosowania do czynności polegającej na przyzwalaniu na czyjąś krzywdę. Niektórzy zakładają ponadto, że już w samym rozróżnieniu obu sposobów postępowania zawarta jest implicite teza o istnieniu własności związanych z moralną między nimi różnicą, które charakteryzują się tym, że towarzyszą dużo częściej - i jakby w sposób naturalny - jednemu zachowaniu niż drugiemu (Tooley, 1994, s. 107-108; Norcross, 2005 s. 460-461; Zimmerman, 2010, s. 610-611).

Niektóre z tych sugestii pozwolą nam zorientować się, jakie empiryczne czynniki uważane są za najbardziej istotne dla dokonania porównawczej wartości obu stanowisk, a być może dostarczą także wiedzy o tym, że pytanie: czy istnieje moralna różnica między czynnością krzywdzenia a przyzwolenia na krzywdę? nie musi mieć zawsze takiego samego punktu odniesienia, lecz może dotyczyć pod pewnym względem odmiennych i nieprzystających do siebie zachowań. Wydaje się więc, że aby przedstawić na nie taką odpowiedź, która byłaby ostateczna i w pełni zasadna, należałoby najpierw zbadać, jak brzmiałaby ona w odniesieniu do każdego z wyróżnionych powyżej przypadków tego rodzaju czynności.

Moralna ocena różnicy występującej między krzywdzeniem a przyzwoleniem na krzywdę dokonywana jest nierzadko w odniesieniu do czynności, które są całkowicie wyizolowane od zewnętrznych i zmiennych czynników związanych z okolicznościami, jakie mogą towarzyszyć ich wykonaniu, a także z własnościami charakteryzującymi wykonujące je podmioty. Zabieg ten ma na celu nie tylko zbadanie, czy różnica ta jest moralnie znacząca sama $w$ sobie, ale służy również do sformułowania argumentu przeciwko tym, którzy skłonni są utrzymywać w tej kwestii pogląd tradycyjny, a mianowicie sądzą, że krzywdzenie jest w każdym przypadku znacząco gorszym 
postępowaniem. Zakłada się tu bowiem, że gdy ktoś tak właśnie myśli, nie zawsze musi dokonywać niewłaściwej oceny moralnej. Niekiedy zdarza się, że czynniki towarzyszące krzywdzeniu w pełni uzasadniają taki osąd. Dokonanie prawidłowego rozróżnienia moralnego nie chroni nas jednak przed możliwością popełnienia poważnego błędu w rozumowaniu, które leży u podstaw tego rozróżnienia. Polega on, najogólniej rzecz ujmując, na tym, że myśląc, iż krzywdzenie jest gorsze od przyzwolenia na krzywdę, nie zauważamy, że nasze przekonanie wynika w istocie rzeczy z obecności tego rodzaju czynników, a nie z różnicy, jaka istnieje per se między krzywdzeniem a przyzwoleniem na krzywdę. Może być więc tak, że pomimo, iż słusznie myślimy, że krzywdzenie jest na ogół gorsze od przyzwolenia na krzywdę, w żadnym razie nie dowodzi to, że różnica między nimi ma sama w sobie jakieś istotne znaczenie moralne (Rachels, 1975, s. 79; Tooley, 1994, s. 107).

Problem, jaki pociągają za sobą tego typu przypadki, polega między innymi na tym, w jaki sposób odróżnić czynność krzywdzenia od czynności sprowadzającej się do przyzwolenia na krzywdę, aby kryteria stanowiące o ich wewnętrznej różnicy nie obejmowały czynników, które mają zmienny charakter i zależą od okoliczności towarzyszących ich wykonywaniu. Na tym etapie rozważań najważniejszym zadaniem nie jest sformułowanie takiej metody odróżnienia obu czynności, która mogłaby być z powodzeniem stosowana w każdych warunkach. Chodzi raczej o wskazanie jakiegoś minimalnego kryterium, umożliwiającego uchwycenie ich odmienności wtedy, gdy rozpatruje się je w całkowitej izolacji od zewnętrznego kontekstu. Wydaje się, że najprostszym sposobem na osiągnięcie tego celu byłoby skupienie się na relacji przyczynowej, jaka w obrębie rzeczywistości fizycznej łączy każdą z tych czynności z jego sprawcą. Prawidłowo rozumiane znaczenie pojęcia „przyzwolenie na krzywdę” zdaje się sugerować, że określane tym mianem zachowanie możliwe jest tylko w okolicznościach, w których sekwencja zdarzeń mogących tę krzywdę wywołać już istnieje lub została właśnie zapoczątkowana. Nie da się w tym sensie przyzwolić na śmierć jakiejś osoby, jeśli jej życie w ogóle nie jest zagrożone, tak samo, jak nie można wykonać czynności polegającej na przyzwoleniu, aby ktoś został obrabowany, o ile nikt tego nie czyni ani nawet nie planuje tak postąpić. Inaczej wygląda jednakże sprawa, gdy wsypujemy truciznę do herbaty, którą osoba ta zamierza wypić lub kiedy włamujemy się do czyjegoś mieszkania i zabieramy znajdujące się tam kosztowności. To, czy w tej sytuacji czyjeś życie lub czyjaś własność były wcześniej zagrożone czy nie, nie ma większego znaczenia, 
gdyż uruchomiona została sekwencja zdarzeń, z powodu której jedna osoba umrze, a druga zostanie okradziona. Tym właśnie krzywdzenie odróżnia się pierwotnie od przyzwolenia na krzywdę - aby możliwe było drugie z nich, musi istnieć już sekwencja zdarzeń, która, będąc całkowicie niezależna od tego typu czynności, może doprowadzić do krzywdy, o której mowa, natomiast krzywdzenie sprowadza się w istocie rzeczy do zapoczątkowania, czy też zainicjowania, zdarzeń, funkcjonujących jako jej przyczyna sprawcza. (Podobny pogląd głosiła Foot, 1967, s. 11-12; 1984, s. 179; 1985, s. 24. Ostateczne stanowisko Foot w tej sprawie było bardziej złożone. Na ten temat zob. Woolward, 2008, s. 262-266. Pewne krytyczne argumenty wobec tego typu kryteriów leżących u podstaw różnicy między krzywdzeniem a przyzwalaniem na krzywdę przedstawił Quinn, 1989, s. 301-303). Choć skutek obu czynności może być podobny, różnią się one między sobą ze względu na odmienną rolę, jaką odgrywają w szeroko rozumianym procesie przyczyniania się do czyjejś krzywdy.

Czy tak pojmowana różnica między krzywdzeniem a przyzwoleniem na krzywdę stanowi - sama w sobie - wystarczającą rację za tym, żeby móc wiarygodnie twierdzić, iż istnieje pomiędzy nimi również różnica moralna? Aby znaleźć prawidłową odpowiedzieć na to pytanie, należałoby rozważyć przypadek obejmujący możliwość wykonania obu czynności, w którym zostałyby one ponadto całkowicie odseparowane od okoliczności zewnętrznych. Warunki te spełnia

Maszyna Tooleya: W pewnym urządzeniu znajduje się dwoje dzieci. Wciśnięcie guzika oznacza zainicjowanie sekwencji zdarzeń, które doprowadzą do tego, że ciało pierwszego z nich zostanie zdeformowane oraz trwale i poważnie uszkodzone, w wyniku czego dziecko to do końca życia będzie kaleką. Gdy guzik nie zostanie wciśnięty, inna sekwencja zdarzeń (np. choroba, której zaistnienie było całkowicie niezależne od czynności związanych z wciśnięciem lub niewciśnięciem guzika) doprowadzi do takiego samego kalectwa drugiego dziecka. Tak więc, jeśli jakaś osoba wciśnie guzik, wykona czynność polegającą na skrzywdzeniu pierwszego dziecka, jeśli natomiast nie wciśnie guzika, pozwoli tym samym, aby podobna krzywda stała się drugiemu dziecku.

Ci, którzy są przekonani, że powstrzymanie się od wciśnięcia guzika nie podlega w tej sytuacji innej ocenie moralnej niż czynność jego wciśnięcia, albowiem w perspektywie zaistnienia krzywdy żadnego znaczenia nie ma to, czy ktoś wciśnie guzik, czy nie, stoją zwykle na stanowisku, że 
nie istnieje nic takiego, jak wewnętrzna różnica moralna między krzywdzeniem a przyzwalaniem na krzywdę. Ich sposób myślenia, znany jako zasada moralnej symetrii zakłada, że nie ma jakichkolwiek podstaw, aby dokonać rozróżnienia moralnego między umyślnym wykonaniem czynności inicjującej proces przyczynowy, który prowadzi do czyjejś krzywdy, a postępowaniem polegającym na powstrzymaniu się od zatrzymania biegu tego rodzaju sekwencji zdarzeń zanim szkoda zostanie wyrządzona (jest to zmodyfikowana wersja poglądu wyrażonego przez Tooleya, 1983, s. 155, 184-186, 190-191).

Istnieje, rzeczywiście, taka wersja zasady moralnej symetrii, z punktu widzenia której różnica między krzywdzeniem a przyzwoleniem na krzywdę nie czyni, sama przez się, moralnego rozróżnienia. Jest tak na przykład wówczas, gdy różnicę moralną między obu czynnościami rozumie się wyłącznie w kategoriach przeciwstawnych sobie wartości, tj. dobra i zła. W takiej perspektywie za złe może być uznane zarówno inicjowanie sekwencji zdarzeń prowadzącej do krzywdy, jak i przyzwolenie na to, aby do podobnej krzywdy doprowadziła jakaś istniejąca już sekwencja zdarzeń. Empiryczna czy pojęciowa odrębność występująca między paradygmatycznymi przykładami obu rodzajów czynności nie ma tu żadnego znaczenia w tym sensie, że sama w sobie nie stanowi czynnika, który może spowodować tego typu różnicę moralną. Tak samo przedstawia się sprawa, kiedy pytamy jedynie o to, czy postępowanie sprawcy jest naganne lub czy zasługuje na potępienie (Rachels, 1975, s. 78-80). Relacja, jaka w jednym i drugim wypadku łączy sprawcę z sekwencją zdarzeń, która prowadzi do czyjejś krzywdy, nie zawsze musi pociągać za sobą tak bardzo zróżnicowaną ocenę jego zachowania. Tak więc, pomimo różnicy istniejącej pod tym względem między czynnością krzywdzenia a przyzwolenia na krzywdę, obie mogą być słusznie uważane za karygodne i moralnie niedopuszczalne. Rzeczy mogą wyglądać jednakże inaczej, gdy przyjmiemy odmienny punkt widzenia, a mianowicie gdy założymy, że zasada moralnej symetrii ustala różnicę między krzywdzeniem a przyzwoleniem na krzywdę w kategoriach stopni istniejących w ramach tej samej wartości. Tutaj nie chodzi już o dokonywanie podziału, który miałby typowo dychotomiczny charakter i prowadziłby do wniosku, że jedna czynność jest zła, a druga dobra, lecz raczej o odpowiedź na pytanie, która z nich jest gorsza czy bardziej naganna (takie rozumowanie zasady moralnej symetrii przyjmują Lichtenberg, 1982, s. 19-36; Nesbitt, 2010, s. 287-291; Liu, 2012, s. 63-81; Callahan, 2000, s. 77-83). 
Ani pierwsza, ani druga wersja nie wyklucza, wbrew temu co się niekiedy twierdzi, słabej tezy zwolenników moralnego rozróżnienia, według której nie sposób zaprzeczyć, iż może zdarzyć się czasami tak, że krzywdzenie będzie słusznie uważane za moralnie gorsze od przyzwolenia na krzywdę. Taka sytuacja może mieć na przykład miejsce wówczas, gdy czynniki zewnętrzne towarzyszące pierwszej czynności, jak choćby motywacja sprawcy lub możliwość zapobiegnięcia krzywdzie, będą moralnie znacząco gorsze w porównaniu do tych, które towarzyszą czynności drugiej, lub w porównaniu do czynności przyzwalania na krzywdę, którym nie towarzyszą żadne tego rodzaju czynniki. Na pierwszy rzut oka uwaga ta wydaje się w pełni sensowna oraz wysoce koncyliacyjna w stosunku do tych, którzy odrzucają zasadę moralnej symetrii, niemniej jednak sądzę, że należałoby tu zalecać zachowanie daleko posuniętej ostrożności oraz zdrowego sceptycyzmu. Równie dobrze wynikać z niej może bowiem zupełnie odmienne przekonanie, a mianowicie, że wyciąganie na tej podstawie wniosku o istnieniu moralnej różnicy między jednym a drugim postępowaniem nie jest do końca wiarygodne, gdyż polega w istocie rzeczy na pomyleniu sądu o wzajemnej wartości tych czynników - lub sądu o wartości, z jednej strony, czynników, a z drugiej strony, czynności - z porównawczą oceną wartości, jakie ma każde tego rodzaju postępowanie, gdy rozpatrujemy je w całkowitej izolacji, tj. same w sobie.

Jeśli uważamy Maszynę Tooleya za przykład, który na płaszczyźnie zdrowego rozsądku czy intuicji miałby ostatecznie potwierdzać słuszność zasady moralnej symetrii w odniesieniu do wszystkich tego typu paradygmatycznych przypadków krzywdzenia oraz przyzwolenia na krzywdę, musimy postawić pytanie dotyczące jego wiarygodności jako źródła takiego uzasadnienia. Czy faktycznie rzeczą moralnie obojętną jest to, czy guzik zostanie czy nie zostanie wciśnięty? Każdy, kto chciałby podjąć w tej sprawie właściwą decyzję, powinien nie tylko wiedzieć, która czynność jest nieodłącznie związana z krzywdzeniem, a która z przyzwoleniem na krzywdę, ale powinien zdawać sobie również sprawę z konsekwencji, jakie powoduje każda z nich oraz ze wzajemnej zależności między ich wykonaniem a losem uwięzionych dzieci. Kiedy ktoś postanawia, że nie wciśnie guzika i tak rzeczywiście czyni, jego postępowanie ma pewną moralnie istotną konsekwencję, a mianowicie powoduje, że istniejąca już i niezależna od takiej decyzji sekwencja zdarzeń doprowadzi do krzywdy dziecka, natomiast kiedy postanawia wcisnąć guzik, a następnie wciela swoją decyzję 
w życie, jego postępowanie w moralnie znaczący sposób dotyczy dwojga dzieci: z jednej strony przyczynia się do tego, że zainicjowana taką decyzją sekwencja zdarzeń doprowadzi do krzywdy jednego dziecka, z drugiej zaś strony powoduje, iż jakieś inne dziecko uniknie krzywdy, którą doznałoby, gdyby nie wcisnął guzika. Wykonując czynność krzywdzenia osoba ta zmienia naturalny bieg rzeczy przez wywołanie krzywdy u dziecka, które by jej nie doznało, i tym samym uwalnia od podobnej krzywdy drugie dziecko, które w innym wypadku zostałoby niechybnie skrzywdzone.

II

Czy można opisać tę sytuację tak, jak zrobiła to Helen Frowe (2010, s. 58-59; szersze omówienie stanowiska Frowe znaleźć można w Simkulet, 2015, s. 93-104), a mianowicie mówiąc, że osoba wciskająca guzik niejako przekierowuje krzywdę na dziecko, które nie doświadczyłoby jej bez wciśnięcia guzika, i w ten sposób chroni przed taką samą krzywdą inne dziecko? Odpowiedź może być twierdząca pod warunkiem, że zdajemy sobie sprawę, iż nie chodzi tu bezpośrednio ani wyłącznie o motywację, która leżała u podstaw tej czynności, lecz jedynie o wykorzystanie okazji, jaką stwarza możliwość zastosowania antropomorficznej funkcji języka w odniesieniu do bezosobowych z istoty rzeczy procesów i zjawisk. Jeśli dobrze rozumiem stanowisko Frowe, jej intencją nie było stwierdzenie, że osoba ta, wciskając guzik, miała zamiar zmienić naturalny bieg rzeczy, aby ochronić kogoś od krzywdy, lecz że zrobiła coś, co może być poprawnie zinterpretowane $\mathrm{w}$ taki właśnie sposób. W świetle przyjętej interpretacji wyrażenie „przekierowała krzywdę” nie oznacza, że mamy do czynienia z tą sama krzywdą w przypadku jednego i drugiego dziecka, lecz raczej, że chodzi tu o taką samą wielkość krzywdy albo o podobny zakres bądź intensywność jej doznania (tylko gdyby między jedną a drugą krzywdą zachodziła identyczność numeryczna, można byłoby mówić literalnie o jej przekierowaniu), a to sugeruje, iż wypowiadając się w ten sposób, zakłada się jedynie, że osoba ta powoduje swoim postępowaniem, że pewne dziecko nie doświadczy krzywdy, która jest podobna do tej, jakiej doświadczy inne dziecko. Tak samo przedstawia się sprawa, gdy w odniesieniu do opisanego przykładu robimy założenie, że poprzez wciśnięcie guzika osoba ta kogoś „chroni” - w żadnym razie nie chodzi tu o to, że chcemy przez to powiedzieć, 
iż jej zachowanie ma taki właśnie cel, czy też, że podyktowane było takim zamiarem, lecz głównie o to, że wykonanie tej czynności ma również i ten skutek, że zapobiega krzywdzie dziecka.

W opisanej sytuacji różnica między krzywdzeniem a przyzwoleniem na krzywdę zakłada odmienną relację pomiędzy osobami, które są potencjalnymi ofiarami krzywdy, a istniejącą już sekwencją zdarzeń, która do takiej krzywdy prowadzi. Z punktu widzenia obiektywnej rzeczywistości fizycznej tylko jedno z dzieci jest zagrożone krzywdą, gdyż stanowi ono - z jakichś przypadkowych i nieznanych powodów, za które nikogo nie można obarczyć odpowiedzialnością - część procesu, który stanie się ostatecznie jej przyczyną. Drugie dziecko takiemu zagrożeniu w ogóle nie podlega. Jeśli pozwolimy, aby rzeczy biegły swoim własnym, naturalnym torem, to możemy się spodziewać, że nie zostanie ono w ten sposób skrzywdzone. Czy sąd, że nie ma wewnętrznej różnicy moralnej między krzywdzeniem a przyzwalaniem na krzywdę może zostać poprawnie uzasadniony przekonaniem, że w tym wypadku wciśnięcie guzika ma taką samą wartość, jak wstrzymanie się przed wykonaniem tej czynności, i że w moralnej perspektywie obojętne jest, co zostanie zrobione? Gdyby tak faktycznie było, oznaczałoby to nie tylko, że możemy z rozmysłem krzywdzić niewinnych ludzi - którzy z obiektywnego punktu widzenia nie podlegają takiemu zagrożeniu - w sytuacji, w której zdajemy sobie sprawę z tego, że nasze postępowanie chroni przed podobna krzywdą taka samą liczbę jakichś innych ludzi, ale oznaczałoby także, że zachowując się w ten sposób, nie postępujemy gorzej niż wówczas, gdy nie ingerujemy w naturalny bieg rzeczy prowadzący do podobnego celu. Opisana zależność, choć może znacząco wpływać na to, jakie ostatecznie zajmiemy w tej sprawie stanowisko, sama w sobie nie stanowi jednakże wystarczającego uzasadnienia dla negatywnej odpowiedzi na to pytanie. Aby tak się stało, trzeba czegoś jeszcze. Wydaje się, iż w tym celu należałoby wskazać dodatkowo jakąś istotną rację za tym, dlaczego powinniśmy uważać, że niedozwolone moralnie i dużo gorsze jest inicjowanie sekwencji zdarzeń prowadzących do krzywdy jednej osoby, gdy zdarza się tak, że tego rodzaju zachowanie zapobiega podobnej krzywdzie, jakiej doznałby z kolei ktoś inny.

Taką racją nie może być przekonanie, że po to tylko krzywdzi się jedno z dzieci, aby zapobiec krzywdzie drugiego z nich. Oznaczałoby to bowiem, że sprawca ma motyw nakłaniający go do wykonania czynności polegającej na naciśnięciu guzika, którego byłby pozbawiony w przypadku czynności alternatywnej. Teza ta byłaby sprzeczna z założeniem leżącym 
u podstaw porównawczej wartości czynności krzywdzenia i przyzwolenia na krzywdę, dokonywanej w odniesieniu do przypadków paradygmatycznych, a więc takich, z których wyizolowane zostały wszystkie przypadkowe i zmienne czynniki zewnętrzne. Moralna różnica między krzywdzeniem a przyzwoleniem na krzywdę, która ma charakter wewnętrzny i jest różnicą samą w sobie, powinna dotyczyć natury obu czynności zawartej w pojęciach służących wyłącznie do ich rozróżnienia. Wynika z tego, że porównanie moralnej wartości dwóch sposobów postępowania, jakie implikuje Maszyna Tooleya, ma sens tylko wtedy, gdy założy się, że osoba, która może bez trudu wcielić je w życie, nie dokona wyboru na podstawie istniejącej pomiędzy nimi zależności. Ponieważ jednak tego rodzaju zależność jest obiektywna i ma faktycznie miejsce $\mathrm{w}$ tym przypadku, trzeba $\mathrm{z}$ konieczności zakładać, że osoba ta nie może podjąć decyzji na temat swojego postępowania w okolicznościach, w których tego typu zależność by nie występowała. Każdy więc, kto utrzymuje, że między jedną a drugą czynnością zachodzi znacząca różnica moralna, musi zdawać sobie sprawę z tego, iż jej źródeł nie można dopatrywać się w fakcie, że jedna z nich została dokonana pod wpływem przekonania o występującej pomiędzy nimi zależności, lecz w tym, że taka zależność pomiędzy nimi rzeczywiście istnieje. Nie wydaje się, aby w tej sytuacji rzeczą nieistotną było to, która czynność zostanie wykonana. Chociaż skutek, jaki powoduje wciśnięcia guzika jest pod pewnym względem taki sam, jak rezultat czynności polegającej na powstrzymaniu się od wciśnięcia guzika - gdyż w jednym i drugim przypadku mamy do czynienia z podobną krzywdą dziecka - nie musi to jednakże prowadzić do wniosku, że moralnie obojętna jest różnica przyczynowa między zajściem jednej a drugiej krzywdy, ani też, że nie ma moralnego znaczenia to, jaka pomiędzy nimi istnieje zależność.

Dlaczego tak się dzieje? Po części z powodu pewnych metafizycznych założeń, które leżą u podstaw rozważanego przypadku. Zarysowany przez Maszynę Tooleya obraz jest mniej więcej taki:

Dwie osoby, A i B, z nieznanych przyczyn znajdują się w odmiennych, pod pewnym względem, okolicznościach, w świecie, który charakteryzuje się między innymi tym, że składa się na niego niezwykle złożona konfiguracja rozlicznych sekwencji zdarzeń. Osoba A jest częścią jakiegoś istniejącego już procesu przyczynowego, który doprowadzi do jej krzywdy. B sytuuje się natomiast poza jego granicami i z tego powodu jest wolna od takiego zagrożenia. Każdy, kto staje wobec tego rodzaju 
obiektywnych faktów, może wykonać dwie czynności - przyzwolić na krzywdę A lub zainicjować sekwencję zdarzeń, która doprowadzi do krzywdy B. W pierwszym wypadku sprawca akceptuje świat takim, jakim on jest, w drugim modyfikuje go poprzez ingerencję w jego naturalny porządek. Podejmując decyzję w tej sprawie, ma on świadomość, że między jedną a drugą czynnością istnieje zależność, której zmienić nie można. Polega ona na tym, że jeśli przyzwoli się na krzywdę osoby A, nie spowoduje to w najmniejszym stopniu zmiany okoliczności, w jakich znajduje się osoba $B$, jeśli jednak zapoczątkowany zostanie proces przyczynowy prowadzący do krzywdy B, radykalnej zmianie ulegnie funkcjonująca już sekwencja zdarzeń prowadząca $\mathrm{z}$ kolei do krzywdy A - zostanie ona zatrzymana, w wyniku czego A nie dozna szkody, która wcześniej była nieunikniona.

Teza zawarta w zasadzie moralnej symetrii - że nie da się ustalić różnicy między czynnością krzywdzenia a przyzwolenia na krzywdę nawet w ramach tej samej wartości - prowadzi do wniosku, iż w opisanej sytuacji sprawca ma przyzwolenie na taką ingerencję w naturalny stan rzeczy, która powoduje przekierowanie krzywdy na inną osobę. Tym samym zakłada, że de facto nie istnieją moralne zasady, które w równym stopniu zapobiegałyby zarówno temu, aby doprowadził on swoim postępowaniem do całkowitego wyeliminowania ryzyka doznania krzywdy przez osobę, która była nim wcześniej zagrożona, jak i temu, by zainicjował równie duże ryzyko doznania podobnej krzywdy przez osobę postronną (pojęcia „osoba postronna” używam w znaczeniu, jakie zostało zaproponowane przez Thompson, 2009, s. 89-90; moralny status osoby postronnej nie zawsze jest uzasadniany w taki sam sposób, zob. Otsuka, 1992, s. 84-88, McMahan, 1994, s. 266-271), która nie tylko nie była zagrożona tego typu ryzykiem, ale nie była też w żaden sposób przyczynowo uwikłana w powstanie zagrożenia, jakiemu podlega pierwsza osoba.

Taki punkt widzenia uważam za błędny. Stoję na stanowisku, że odmienne usytuowanie w obrębie łańcucha przyczynowo-skutkowego może rodzić poważne konsekwencje moralne i że tak jest właśnie w tym wypadku. Pogląd ten zbieżny jest z podzielanym powszechnie przekonaniem, że tam, gdzie warunkiem uwolnienia kogoś od szkody, jaka niechybnie się mu przydarzy na skutek istniejącej już sekwencji zdarzeń, jest wyrządzenie podobnej szkody postronnej osobie, która nie tylko, że takiemu zagrożeniu sama nie podlega, ale nie przyczyniła się do tego, że podlega mu ktokolwiek inny - to powinna być bardziej chroniona moralnie. Zmiana preferencji jest 
teoretycznie możliwa, lecz mogłaby zostać dokonana wyłącznie na podstawie faktów, które wskazywałyby w sposób jednoznaczny, że z jakichś moralnie istotnych powodów byłoby w tej sytuacji lepiej, gdyby skrzywdzona została taka osoba.

Oczywiście nie sposób zakładać, że istnienie takich czynników jest z góry wykluczone. Jeśli decyzje dotyczące moralnej wartości czyjegoś postępowania podejmowane będą - jak to się najczęściej robi w praktyce - na podstawie ontologicznej zasady maksymalizacji dobra, według której zawsze jest moralnie lepiej, gdy ilość dobra w świecie jest większa, to nie można wykluczyć, że ingerencja w bieg rzeczy i przekierowanie krzywdy na osobę postronną może dużo bardziej zadośćuczynić tego typu wymaganiom, aniżeli zgoda na to, aby sprawy biegły swoim naturalnym torem. W odniesieniu do przypadku, którego dotyczy Maszyna Tooleya, oznaczałoby to, że trzeba by wziąć pod uwagę również taką sytuację, w której doprowadzenie do kalectwa dziecka spełniającego warunki osoby postronnej mogłoby przynieść więcej dobra niż jakakolwiek inna czynność możliwa do wykonania w tych okolicznościach. Byłoby lepsze na przykład wówczas, gdyby okazało się, że osoba, którą stanie się później to dziecko, w dużo większym stopniu szkodzić będzie innym ludziom, bardziej uszczupli zasoby dające szczęście ogółowi czy też znacznie szerzej będzie oddziaływać swoim zgubnym przykładem, przyczyniając się w ten sposób do zwielokrotnienia liczby tych, którzy z powodu podjętej decyzji poniosą niepowetowane straty. Mimo że nie można temu zaprzeczyć, fakt ten nie stanowi jednakże liczącego się argumentu. Nie da się go zastosować do żadnego przykładu, który byłby właściwym przedmiotem analizy mającej na względzie jedynie paradygmatyczne przypadki krzywdzenia i przyzwalania na krzywdę, a wzięcie pod uwagę tak szerokiego spektrum możliwości ma w konsekwencji również i tę niekorzystną własność, że w żadnym razie nie prowadzi do odpowiedzi na pytanie, czy istnieje pomiędzy nimi jakaś wewnętrzna różnica moralna. Rozwiązanie tego typu kwestii nie bierze pod uwagę maksymalizacji dobra o charakterze utylitarystycznym, które wiązałoby się z istnieniem rozmaitych czynników zewnętrznych. W takich okolicznościach nie byłoby bowiem do końca jasne, czy ocena wzajemnej wartości krzywdzenia i przyzwolenia na krzywdę zależy od wartości, jaką nadajemy wyłącznie tym czynnikom, czy też od natury samych czynności, kiedy wyizolowane zostaną z nich wszystkie zmienne. Brak tej wiedzy mógłby zrodzić całkowicie nieprzystające do siebie - lecz w równym stopniu uprawnione - interpretacje tezy, że 
pierwsza czynność jest znacząco gorsza od drugiej: niektórzy doszliby do wniosku, że jest tak dlatego, gdyż różnica między nimi jest sama w sobie moralnie znacząca, natomiast inni byliby zdania, że tego rodzaju rozróżnienie spowodowane jest istnieniem tych czynników, a nie jedynie różnicą, jaka dzieli obie czynności.

Twierdzenie, iż z moralnego punktu widzenia nie da się przeprowadzić ostrej linii demarkacyjnej między wciśnięciem a niewciśnięciem guzika, zakłada błędne przekonanie, że przy dokonywaniu porównawczej oceny obu przypadków w ogóle nie jest istotny sposób, w jaki doprowadza się do krzywdy dziecka, a jedyne bądź najważniejsze znaczenie ma tylko to, że cokolwiek zrobimy, to i tak jakieś dziecko zostanie skrzywdzone. Takiego myślenia nie można akceptować. Gdy wciskamy guzik, wykonywana przez nas czynność stanowi przyczynę sprawczą krzywdy, jakiej dozna jedno z dzieci, natomiast gdy decydujemy się tego nie czynić, wówczas nie można sensownie twierdzić, że ciąży na nas podobnego rodzaju odpowiedzialność za to, co się stanie. W pierwszym wypadku to my sami jesteśmy przyczyną krzywdy, podczas gdy w drugim istnieje ona poza nami i jest od nas całkowicie niezależna pod tym względem. Wydaje się rzeczą niewyobrażalną, aby stojąc przed wyborem, na jaki skazuje nas Maszyna Tooleya, można było pomijać tę istotną różnicę. Sądzę, że każdy, kto zdawałby sobie z tego wszystkiego sprawę i wiedziałby dokładnie, jakimi niewielkimi dysponuje możliwościami w tym względzie, wolałby z pewnością uniknąć sytuacji, w której to on krzywdzi dziecko, na rzecz okoliczności, w których dziecko zostaje skrzywdzone przez coś, co istnieje obiektywnie i funkcjonuje w pełni samoistnie.

Aby to lepiej wyjaśnić, popatrzmy na całą sytuację oczami dzieci, które narażone są na szkody i wynikające $z$ nich cierpienia. W tej perspektywie nie może być bez znaczenia to, że każde z nich miałoby prawo zapytać o racje leżące u podstaw dokonanego przez nas wyboru. Gdy takie pytanie stawia dziecko, w odniesieniu do którego jedynie przyzwoliliśmy, aby doznało krzywdy, odpowiedź wydaje się jasna i zrozumiała: literalnie rzecz ujmując, to nie my je skrzywdziliśmy; dopuściliśmy jedynie do tego, że poniosło ono szkody z powodu istniejącej już sekwencji zdarzeń, której było - z jakichś nieznanych i zapewne przypadkowych powodów - immanentną częścią; i co ważne - zrobiliśmy tak w okolicznościach, w których zapobieżenie jego krzywdzie z konieczności wiązałoby się ze skrzywdzeniem innego dziecka, które nie tylko nie było w taki sposób zagrożone, ale nie przyczyniło się 
również w żaden sposób do zainicjowania tej feralnej sekwencji zdarzeń, a ponadto przekierowanie na nie krzywdy nie spowoduje, iż zaistniałoby mniejsze zło od tego, jakie jest udziałem dziecka, którego krzywda miała miejsce $\mathrm{z}$ powodu naszego przyzwolenia. Inaczej jednakże miałyby się sprawy w odniesieniu do dziecka, które zostałoby skrzywdzone wyłącznie z naszego powodu. W takiej sytuacji to nie jakaś przypadkowo uruchomiona sekwencja zdarzeń spowodowałaby jego krzywdę, lecz my sami bylibyśmy jej przyczyną. Nie chcę przez to powiedzieć, że czynność krzywdzenia zawsze jest niesłuszna, twierdzę tylko, że w opisywanych okolicznościach nie zachodzą warunki, które uzasadniałyby odmienną ocenę. Zachowując się w ten sposób, rozmyślnie skrzywdzilibyśmy dziecko mające status osoby postronnej, a to oznaczałoby, że nie moglibyśmy mieć żadnej liczącej się racji moralnej uzasadniającej nasz wyborów i następujące po nim postępowanie. Nawet gdyby wziąć pod uwagę wszystkie poważniejsze wątpliwości dotyczące kwestii całkowitego nieistnienia racji moralnych w takim wypadku (Murphy, 1979, s. 12-20), i tak byłoby jasne, że obiekcja wobec czynności krzywdzenia byłaby o wiele większa aniżeli ta, którą można by zastosować wobec aktów przyzwalania na krzywdę.

\section{Bibliografia}

Callahan, D. (2000). Killing and Allowing to Die. W: D. Callahan, The Troubled Dream of Life. In Search of a Peaceful Death. Washington: Georgetown University Press.

Foot, P. (1967). The Problem of Abortion and the Doctrine of Double Effect. Oxford Review, 5, 1-7.

Foot, P. (1984). Killing and Letting Die. W: J.L. Garfield, P. Hennessey (red.), Abortion: Moral and Legal Perspectives. Amherst: University of Massachusetts Press.

Foot, P. (1985). Morality, Action, and Outcome. W: T. Honderich (red.), Morality and Objectivity. London: Routledge.

Frowe, H. (2010). Killing John to Save Mary: A Defence of the Moral Distinction Between Killing and Letting Die. W: J.K. Campbell, M. O’Rourke, H.S. Silverstein (red.), Action, Ethics, and Responsibility. Cambridge, MA: The MIT Press.

Lichtenberg, J. (1982). The Moral Equivalence of Action and Omission. Canadian Journal of Philosophy, 12, 19-36. 
Liu, X (2012). A Robust Defence of the Doctrine of Doing and Allowing. Utilitas, 24, 63-81.

McMahan, J. (1993). Killing, Letting Die, and Withdrawing Aid. Ethics, 103, $250-279$.

McMahan, J. (1994). Self-Defence and the Problem of Innocent Attacker. Ethics, 104, 252-290.

Murphy, J.G. (1979). The Killing of the Innocent. W: J.G. Murphy, Retribution, Justice, and Therapy. Essays in the Philosophy of Law (s. 3-25). Dordrecht: Springer Netherlands.

Norcross, A. (2005). Killing and Letting Die. W: R.G. Frey, C.H. Wellman (red.), A Companion to Applied Ethics (s. 451-464). Oxford: Blackwell Publishing.

Narveson, J. (2003). We Don't Owe Them a Thing! A Tough-Minded but Soft-Hearted View of Aid to the Faraway Needy. The Monist, 8, 419-433.

Nesbitt, W. (2010). Is Killing No Worse than Letting Die? W: L. Vaughn (red.), Contemporary Moral Arguments. New York: Oxford University Press.

Otsuka, M. (1992). Killing the Innocent in Selfe-Defense. Philosophy and Public Affairs, 23, 74-94.

Quinn, W.S. (1989). Actions, Intentions, and Consequences: The Doctrin of Doing and Allowing. Philosophical Review, 98, 287-312.

Rachels, J. (1975). Active and Passive Euthanasia. New England Journal of Medicine, 292, 78-80.

Simkulet, W. (2015). Frowe's Machine Cases. Filosofiska Notiser, 2, 93-104.

Thomson, J.J. (2009). Obrona własna. W: T. Żuradzki, T. Kuniński (red.), Etyka wojny. Antologia tekstów (s. 76-100). Warszawa: Wydawnictwo Naukowe PWN

Tooley, M. (1983). Abortion and Infaticide. Oxford: Clarendon Press.

Tooley, M. (1994). An Irrelevant Consideration: Killing Versus Letting Die. W: B. Steinbock, A. Norcross (red.), Killing and Letting Die (s. 103-112). New York: Fordham University Press.

Woolard, F. (2008). Doing and Allowing, Threats and Sequences. Pacific Philosophical Quarterly, 89, 261-277.

Zimmerman, M.J. (2010). Responsibility. Act and Omission. W: J. Skorupski (red.), The Routledge Companion to Ethics (s. 607-617). New York: Routledge. 
HURTING AND ALLOWING HARM. PART I: STATUS OF A THIRD PARTY

\section{Summary}

In this article I defence the thesis that there is a morally significant difference between doing harm (or harming) and merely allowing harm to happen. 